(С) Д.В. Петрухина

\title{
МЕСТО ЭТНОКУЛЬТУРНОЙ КОМПЕТЕНТНОСТИ В ФОРМИРОВАНИИ ОБЩЕРОССИЙСКОЙ ГРАЖДАНСКОЙ ИДЕНТИЧНОСТИ*
}

\begin{abstract}
В представленной статье рассматривается структура общероссийской гражданской идентичности и роль этнокультурной компетентности в процессе ее формирования. Автор анализирует нормативнье акты, регламентируюшие государственную национальную политику России, и результаты научных исследований в сфере межэтнических отношений и конструирования идентичностей. Поликультурность российского общества, сложившаяся в результате исторического развития страны, требует от граждан адаптированности и умения строить мирный, конструктивный межэтнический диалог. Наряду с этим, перед государством стоит задача консолидации проживающих на территории России этнических общностей в единую гражданскую нацию. Этнокультурная компетентность, как комплекс личностных качеств, позволяющих человеку создавать ситуаџии успешного межнационального общения, может способствовать решению поставленных задач, если будет рассматриваться как необходимое условие для формирования общероссийской гражданской идентичности и, следовательно, одно из важных направлений воспитательной работь в системе образования.
\end{abstract}

Ключевые слова: этнокультурная компетентность, общероссийская гражданская идентичность, полиэтничность, межэтническое общение, духовно-нравственные ценности, этнокультурное многообразие, национальная политика, воспитание

Полиэтничность российского общества давно воспринимается как объективная реальность. В течение последних 30 лет количество этнических общностей, проживающих на территории России, постоянно возрастало, что подтверждается данными переписей населения. В 1989 г. В России было зафиксировано 128 народов, в 2002 г. - 181, а в 2010 г. уже 193. Этот процесс явился следствием активизации этнической идентичности жителей нашей страны в связи с произошедшими общественными переменами (Кузьмин 1998: 4). Кроме того, высоких показателей достигает в стране как внутренняя миграция, так и приток жителей ближнего и дальнего зарубежья, что еще больше увеличивает этнокультурное многообразие нашего социума. Тенденция усиления полиэтничности требует от каждого гражданина России готовности и умения легко адапти-

Петрухина Дарья Валерьевна - аспирант Института этнологии и антропологии им. Н.Н. Миклухо-Маклая РАН (Москва, Ленинский просп., 32-А). Эл. почта: bianchina@yandex.ru. Petrukhina, Daria V. - Institute of Ethnology and Anthropology Russian Academy of Sciences (Moscow, Leninsky pr., 32-A). E-mail: bianchina@yandex.ru

* Публикуется в соответствии с планом научно-исследовательских работ Института этнологии и антропологии РАН 
роваться и социализироваться в такой среде. Для достижения этой цели необходим не только определенный набор знаний об особенностях проживающих рядом этнических общностей и понимание их поведения, но и навыки бесконфликтного общения, умение находить компромиссное решение проблемы, эмпатия, приверженность общечеловеческим ценностям, а также отсутствие негативных этнокультурных стереотипов. Обладание перечисленными качествами будет способствовать и глубокому осознанию объективности факта этнокультурного многообразия населения России, ощущению единства всех этнических общностей, развитию гражданского самосознания.

Не так давно в отечественном обществоведческом дискурсе применительно к межэтническим отношениям активно развивался концепт толерантности как важнейшего личностного качества гражданина полиэтнического социума. Сегодня, в контексте развития концепции общероссийской гражданской идентичности, формирование толерантности у детей и молодежи представляется узконаправленным процессом. Поскольку основным проявлением названной идентичности должно стать сплочение и мирное сосуществование всех граждан России, недостаточно проявлять терпимость к присутствию и особенностям других народов, необходимо их понимать и использовать общее и различное для построения диалога культур и эффективного, слаженного взаимодействия. Настоящая статья посвящена рассмотрению этнокультурной компетентности как одного из базовых условий для успешного формирования общероссийской гражданской идентичности.

Утверждение в конце 2018 года новой редакции Стратегии государственной национальной политики на период до 2025 г. ознаменовался появлением официального понятийного аппарата, используемого в современной государственной национальной политике. Согласно ему, общероссийская гражданская идентичность представляет собой «осознание гражданами Российской Федерации их принадлежности к своему государству, народу, обществу, ответственности за судьбу страны, необходимости соблюдения гражданских прав и обязанностей, а также приверженность базовым ценностям российского общества» (О Стратегии...). В этом же документе перечисляются единые для всех народов России принципы и ценности, в числе которых патриотизм, служение Отечеству, семья, созидательный труд, гуманизм, социальная справедливость, взаимопомощь и коллективизм.

Ранее Л.М. Дробижева отмечала, что в сознании большей части жителей России государственная идентичность, выражающаяся в признании официальных символов и праздников, лояльности государству и готовности его защищать, неотделима от гражданской - чувства общности с другими гражданами, ответственности за свою и их судьбу (Российская 2009: 10). Такую объединенную государственно-гражданскую идентичность, основу которой составляют ощущение принадлежности к одному народу, солидарность с другими гражданами, признание России своим государством, можно также определить как национальную (Тишков 2010: 17), получившую в официальных документах обозначение «общероссийская и гражданская».

Базовыми принципами интеграции всех населяющих Россию этнических общностей выступают такие категории, как сохранение их исторического наследия и этнокультурной самобытности, уважение традиций, достижение на их основе лучших результатов в развитии единой российской культуры (О Стратегии...). Т.о., одним из важнейших направлений государственной национальной политики выступает сохранение языкового и этнокультурного многообразия населения России. Поскольку современная российская культура вобрала в себя большое количество различных 
элементов в результате взаимодействия русской и других самобытных культур, ставших достоянием всех жителей страны, формирование общероссийской гражданской идентичности возможно на основе российских общекультурных ценностей.

Обобщая вышесказанное, в структуре общероссийской гражданской идентичности можно выделить три взаимосвязанных блока составляющих, обладание которыми определяет ее носителей:

Патриотизм и служение Отечеству, уважение к истории и символам страны.

Общероссийские духовно-нравственные ценности (семья, созидательный труд, гуманизм, социальная справедливость, взаимопомощь и коллективизм).

Уважение и сохранение традиций всех народов России.

В данном случае нас интересует третий блок, связанный с межэтническими отношениями. Он имеет не меньшее значение, чем предыдущие два. Ощущение себя частью общества и солидарность с другими его членами труднодостижимы без осознания и глубокого понимания его поликультурности.

Как уже отмечалось, этнокультурное многообразие населения России обусловлено особенностями процесса ее исторического развития, в течение которого российское общество пополнялось новыми этническими общности. Культура каждой из них является отражением особой картины мира, восприятия и понимание смысла прошлого народа и целей его будущего, осознания каждым индивидом своего места в структуре общества (Кузьмин 1998: 4). Принимая всю эту систему ценностей наряду с языком и материальными элементами культуры, человек осознает себя носителем конкретной этнической идентичности. Учитывая количество проживающих на территории России народов, важно признавать уникальность культуры каждого из них и неизбежность их взаимодействия.

Для адаптации и социализации в таких условиях необходимо формировать и развивать навыки мобилизации знаний, умений, опыта, ценностей и интересов (адекватно конкретной ситуации межэтнического общения) для бесконфликтного взаимодействия с представителями других культур, т.е. этнокультурную компетентность (Поштарева 2007: 96). Рассмотрим подробнее элементы, ее составляющие.

Теоретической базой этнокультурной компетентности выступает система знаний о различных культурах, в том числе и о своей собственной. Под знаниями понимаются любые объективные сведения о материальных и духовно-нравственных ценностях этнической общности, традициях и обрядах, питании, музыке, спорте, способах жизнеобеспечения, географии расселения и т.п. В современном мире источники подобной информации очень разнообразны: школьное образование, тематическая литература, этнографическое кино, средства массовой информации, сеть Интернет, семейное воспитание, личный опыт общения человека и др. Однако данные, почерпнутые из некоторых названных источников, часто являются субъективными, что потенциально может привести к ошибочным суждениям о данной культуре. Следовательно, задача государственной национальной политики - поиск путей передачи исключительно объективной информации и пресечение распространения заведомо неверных культурных стереотипов и предрассудков на их основе.

В комплекс умений в рамках этнокультурной компетентности входят способность внимательно и корректно вести себя в ситуациях межэтнического общения в соответствии с культурными особенностями собеседника, в том числе правильно выбирать средства вербального и невербального общения; умение входить в контакт в полиэтнической среде; владение способами установления позитивных взаимоот- 
ношений; навыки конструктивного разрешения конфликтов. Т.о., перечисленные умения, с одной стороны, являются практическим применением имеющихся знаний этнокультурной направленности, а с другой, вместе с этими знаниями формируют способность понимать особенности каждой культуры, особенности ее формирования и функционирования у каждой этнической общности.

Большую роль в повышении уровня доверительности, доброжелательности и успешности межкультурного общения играют этноспецифические умения: владение традиционными музыкальными инструментами, ремеслами, видами искусства и спорта, а также родным языком собеседника (Поштарева 2007: 100). В этих сферах реализуется интеллектуально-творческий потенциал человека. В процессе обучения таким навыкам и особенностям их применения высока вероятность возникновения ситуаций общения с носителями иной культуры, что может способствовать дальнейшему накоплению личного положительного опыта этнокультурного взаимодействия. При этом важно, чтобы человек сам заинтересовался теми или иными культурными проявлениями и почувствовал желание к ним приобщиться, навязывание в данном случае недопустимо и может привести к обратному результату: отторжению незнакомой культуры и негативному отношению к ней. Это связано с тем, что этнокультурная идентификация в большей степени сопряжена с эмоциональным аспектом сознания, чем с когнитивным (Артеменко 2006: 37).

В целом, эмоционально-нравственный компонент занимает одно из важнейших мест в системе этнокультурной компетентности. В первую очередь необходимо принятие человеком самого факта этнокультурного разнообразия окружающего его социума, как положительного явления, способствующего расширению кругозора, интеллектуальному и творческому обогащению, приобретению нового жизненного опыта (Поштарева 2007: 125). Признаками положительной эмоциональной готовности к межкультурной коммуникации можно считать способность человека преодолевать личностно-психологические барьеры в общении, рефлексию и эмпатию в межэтническом взаимодействии, осознанное стремление к минимизации напряженности между представителями различных культур, умение не поддаваться влиянию этнокультурных стереотипов и предрассудков, непримиримое отношение к расизму, национализму, шовинизму, геноциду (Поштарева 2007: 127). Именно высокие моральные качества человека выступают основой для его способности относиться с уважением к людям, независимо от их этнической, религиозной, социальной принадлежности.

Осознание поликультурности населения России и обретение этнокультурной компетентности играют важную роль в процессах социокультурной модернизации и перехода к гражданскому обществу. В социуме, характеризующемся высокой социальной и культурной мобильностью личности, которой необходимо адаптироваться к таким условиям, самосознание человека выходит за рамки этнического (Кузьмин 1998: 16) и обретает более широкую идентичность - национальную и гражданскую. Таким образом, этнокультурная компетентность способствует расширению сознания индивида и его выходу на новый уровень - общероссийской гражданской идентичности.

Культурная консолидация этнических сообществ в единое гражданское целое путем подготовки каждого индивида к жизни в поликультурном обществе должна стать одной из главных социокультурных задач общеобразовательной школы (Кузьмин 1998: 10). Формирование этнокультурной компетентности наиболее целесообразно проводить в процессе школьного образования, т.к. первый период активной социализации ребенка приходится на время обучения в школе. В дальнейшем человек продолжает 
развивать ее, приобретая новые знания, умения и опыт в течение всей жизни.

Первым шагом в этом направлении будет выявление у младших школьников негативных этнокультурных стереотипов и активная борьба с ними. Затем необходимо помочь детям осознать положительные стороны поликультурности общества, возможные перспективы, открывающиеся благодаря ей, а также постараться заинтересовать какими-либо проявлениями культуры в зависимости от индивидуальных особенностей конкретного ребенка. На этих двух этапах большую роль играет работа школы с родителями: комплексный подход будет способствовать лучшему пониманию условий воспитания в семье, выявлению и поддержке личностных качеств, интересов и стремлений ребенка.

В дальнейшем в школе происходит планомерное формирование элементов этнокультурной компетентности в урочной, в первую очередь это касается предметов гуманитарного цикла, и внеурочной деятельности. Параллельно начинается формирование общероссийской гражданской идентичности. Этот двунаправленный процесс опирается на духовно-нравственное воспитание учащихся, которое в перспективе должно обеспечить поддержание межэтнического мира и согласия народов России (Данилюк 2009: 13). К духовно-нравственным ценностям, кроме перечисленных в Стратегии государственной национальной политики, относятся чувства долга и чести, справедливости, дружелюбия и милосердия, сопереживания, а также позитивное отношение к людям (Об утверждении... 2015). Относительно школьных учебных планов вышеназванный этап приходится на уровень основного общего образования (5-9 классы) с последующим развитием в старшей школе (10-11 классы). Поскольку учащиеся подросткового возраста большое значение придают процессу общения со сверстниками, этот возрастной период наиболее благоприятен для организации совместной деятельности представителей различных культур, имеющей для всех участников эмоционально-ценностное значение.

T.о., этнокультурная компетентность как комплекс знаний и личностных качеств отношения к другим людям, используемый при контактах с людьми иной национальности, с одной стороны, является условием формирования общероссийской гражданской идентичности, а с другой - ее неотьемлемой частью. Воспитание общечеловеческих нравственных качеств гуманизма, взаимопомощи и коллективизма возможно при сформированности у личности, проживающей в условиях этнокультурного и языкового многообразия, этнокультурной компетентности, так как она обеспечивает создание ситуации успешного общения с представителями других культур. Ответственность за подготовку и адаптацию человека к жизни в поликультурном социуме, за трансляцию общероссийских духовно-нравственных ценностей лежит, в первую очередь, на системе образования.

\section{Источники и материалы}

О Стратегии государственной национальной политики Российской Федерации на период до 2025 года. Указ Президента РФ от 19.12.2012 N 1666 (ред. от 06.12.2018) // СПС КонсультантПлюс. http://www.consultant.ru/cons/cgi/online.cgi?req=doc\&base=LAW\&n=312941\&d $\mathrm{st}=1000000001 \# 07649996621139434$ (дата обращения 09.01.2019).

Об утверждении Стратегии развития воспитания в Российской Федерации на период до 2025 года. Распоряжение Правительства РФ от 29.05.2015 N 996-p. // СПС КонсультантПлюс. http://www.consultant.ru/cons/cgi/online.cgi?req=doc\&base=LAW\&n=180402\&d $\mathrm{st}=1000000001$ (дата обращения 15.01.2019). 


\section{Научная литература}

Артеменко О.И. Формирование идентичностей в многонациональном российском обществе: роль школьного образования // Вестник российской нации, 2006. № 3 (48). С. 24-41.

Данилюк А.Я., Кондаков А.М., Тишков В.А. Концепция духовно-нравственного развития и воспитания личности гражданина России. М.: Просвещение, 2009. -24 с.

Кузьмин М.Н. Полиэтничность российского общества и задачи системы образования как инструмента модернизации России. М.: ИНПО, 1998. - 28 с.

Поштарева T.B. Формирование этнокультурной компетентности учащихся в полиэтнической образовательной среде. Дисс. докт. пед. наук. Ставрополь, 2007. 385 с.

Российская идентичность в Москве и регионах / Отв. ред. Л.М. Дробижева. М.: Институт социологии РАН; МАКС Пресс, 2009. 268 с.

Тишков В.A. Российский народ: кн. Для учителя. М.: Просвещение, 2010. 191 с.

Artemenko, O.I. 2006. Formirovanie identichnostey v mnogonatsionalnom rossiyskom obschestve: rol shkolnogo obrazovaniya [The formation of identities in multinational Russian society: the role of school education]. Vestnik rossiyskoy natsii, 3 (48): 24-41.

Danilyuk, A.Ya., A.M. Kondakov, and V.A. Tishkov. 2009. Kontseptsiya duhovno-nravstvennogo razvitiya $i$ vospitaniya lichnosti grazhdanina Rossii [The concept of spiritual and moral development and education of the personality of a citizen of Russia]. Moscow: Prosveschenie.

Kuzmin, M.N. 1998. Polietnichnost rossiyskogo obschestva i zadachi sistemyi obrazovaniya kak instrumenta modernizatsii Rossii [The multi-ethnicity of Russian society and the tasks of the education system as a tool for modernizing Russia]. Moscow: INPO.

Poshtareva, T.V. 2007. Formirovanie etnokulturnoy kompetentnosti uchaschihsya v polietnicheskoy obrazovatelnoy srede [Formation of ethnocultural competence of students in a multi-ethnic educational environment]. PhD diss., Stavropol.

Drobizheva, L.M. 2009. Rossiyskaya identichnost v Moskve i regionah [Russian identity in Moscow and the regions]. Moscow: Institut sotsiologii RAN; MAKS Press.

Tishkov, V.A. 2010. Rossiyskiy narod: kn. Dlya uchitelya [Russian people: a book for the teacher]. Moscow: Prosveschenie.

Petrukhina, Daria $V$.

\section{The Role of Ethnocultural Competence in the Formation of the all-Russian National Identity}

This article discusses the structure of all-Russian national identity and the role of ethnocultural competence in its formation. The author analyzes the regulations that govern the state national policy of Russia, and the results of scientific research in the field of interethnic relations and the construction of identities. The multiculturalism of Russian society, which has developed as a result of the country's historical development, requires citizens to be able to build a peaceful and constructive interethnic dialogue. Along with this, the state faced the task of consolidating the ethnic communities living in Russia into a single nation. Ethnocultural competence in this article is seen as a set of personal qualities that allow a person to establish successful interethnic communication. It can contribute to the solution of this task, if considered as a necessary condition for the formation of an all-Russian national identity and, therefore, one of the important focuses of the educational system.

Key words: ethnocultural competence, all-Russian national identity, multi-ethnicity, interethnic communication, moral values, ethnocultural diversity, national policy, education 